\title{
Viewpoint The Quivira Coalition and the New Ranch: A view from "out of the box."
}

\author{
By Courtney White
}

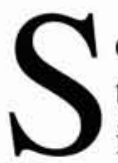
even years ago, a rancher and two conservationists had what we thought was a good idea: create a place where ranchers, environmentalists, scientists, state and federal land managers could explore our common interests instead of argue our differences.

It wasn't a terribly novel idea at the time. In pockets across the West groups of ranchers, federal managers and environmentalists, such as the "Six-onsix" effort in Arizona, had been attempting to find common ground for a while. Nor was it a terribly radical idea. Collaboration and cooperation, afterall, were hallmarks of the Old West - much more so than the romanticized solitary desperado or high plains drifter.

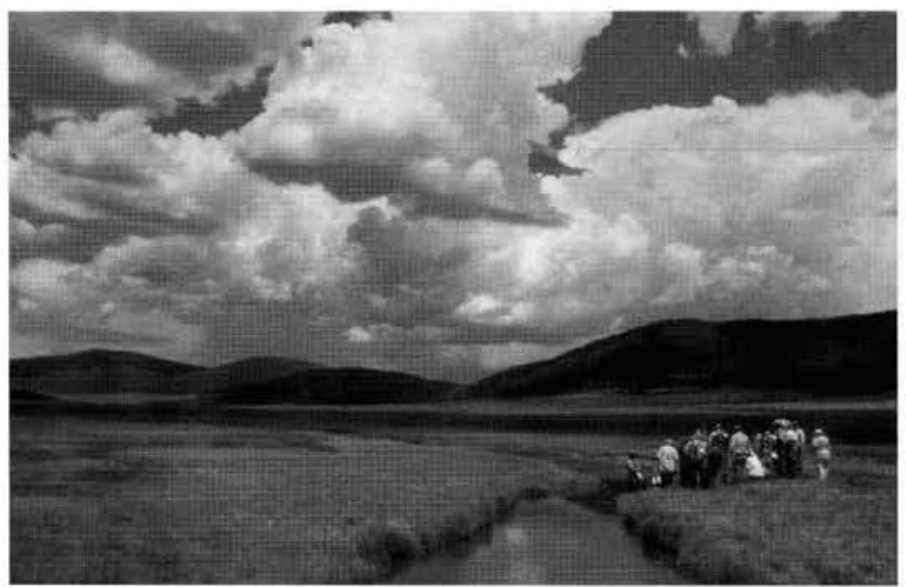

Quivira Coalition workshop on riparian health-held in the Valles Caldera National Preserve, above Los Alamos, New Mexico.

It was novel and radical enough, however, to kick us "out of the box." First off, there wasn't much talk going on between ranchers and environmentalists in New Mexico, a state known in recent years more for confrontation than collaboration. Second, what talk there was, wasn't producing much in the way of improvement on the ground ecologically or economically. And third, time seemed to be running backward on ranching, if not running out altogether.

At the time, the grazing "debate" in the Southwest was dominated by a bitter struggle between hardheaded ranchers and hard-headed environmentalists in a forest wilderness north of Silver City. The Diamond Bar fight, as it came to be called, was a classic brawl between unbending extremes, with the government, and everyone else, stuck in the middle. And as both sides brawled, one could hear the clock ticking on the things we all cared about - the land, the wildlife, and the viability of local communities.

So, it was more out of a sense of frustration, rather than revelation, that The Quivira Coalition came into being.

Following the lead of other "common ground" efforts, we vowed not to do lawsuits or legislation, sticking instead to the grassroots - literally the "grass" and the "roots." It was our belief that the grazing debate needed to start over at the place it mattered most - on the ground. We knew this would be a slow and difficult process, but we also knew it was the only approach that would deliver long-term change.

We also tried something new - we refused to become facilitators or mediators, deciding instead to create a "third position" outside of the continuum of argument. We were not interested in prying open closed minds or becoming engaged in the shouting match over the role of livestock in the Southwest. Instead, we invited people to join us to talk about advances in progressive ranch management, environmental restoration, scientific monitoring, and collaborative stewardship. We called this position The New Ranch.

We knew this approach was a gamble. When we organized our first workshop in a church in Santa Fe in June, 1997, we sent out flyers to every moderate rancher, environmentalist, land manager and scientist we knew. When fifty people showed up, we knew we had a tiger by the tail. Just how big the tiger was, we had no idea. 


\section{The Quivira Coalition}

"Quivira" is a Spanish colonial term for an elusive golden city, always just over the horizon. On maps from the $1600 \mathrm{~s}$ it also designated unexplored territory. This seemed an apt metaphor for our fledgling organization - we were rushing off into uncharted country chasing an elusive dream. A lot of people thought we were crazy.

Fortunately, we had very good guides. In fact, most of the trailblazing had already been done by others - by innovative ranchers who were herding their cattle together to control their impact on the land; by scientists who were quantifying the effects of this new management on land health; by range and riparian consultants who were steering their clients in new directions; and by state and federal land managers who were willing to implement these new ideas on public land. The biggest chore that remained, it seemed to us, was spreading the news.

But we also "walked the talk" by initiating collaborative, on-the-ground demonstration projects. The first took place on Macho Creek, north of Deming, New Mexico. Working with the State Land Office, the local permittee, and Quail Unlimited, we helped construct two-and-a-half miles of electric fence along an overgrazed stretch of riparian area. The idea was to switch the grazing season from yearlong to dormant (winter) use and monitor the effects. Sixteen months later, the ecological rebound was dramatic.

In Quemado, we helped third-generation rancher Jim Williams grow more grass and repair relations with the Forest Service by assisting him to switch to a planned grazing model. Near Cuba, we hired

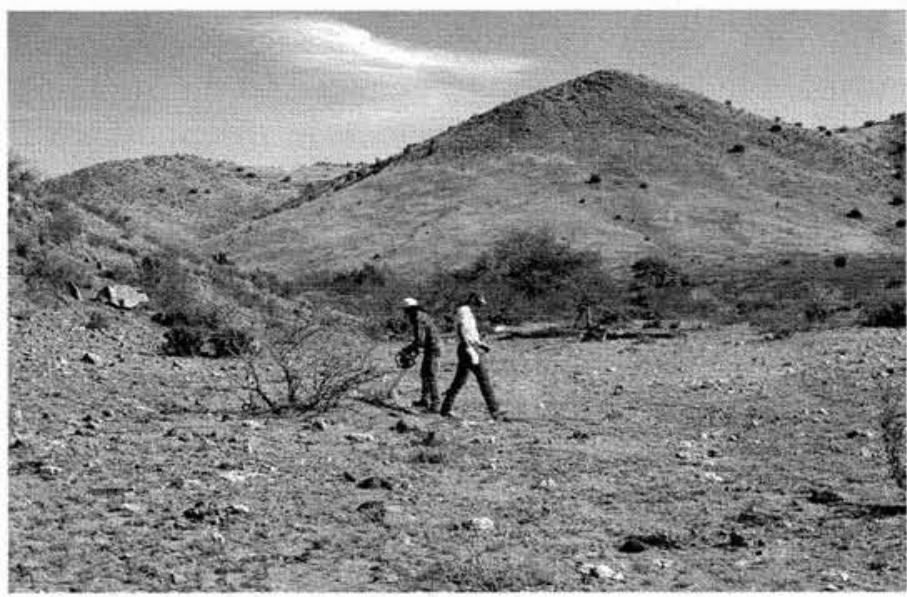

Macho Creek, located north of Deming, New Mexico, May 1998-Before" the switch to dormant season grazing.

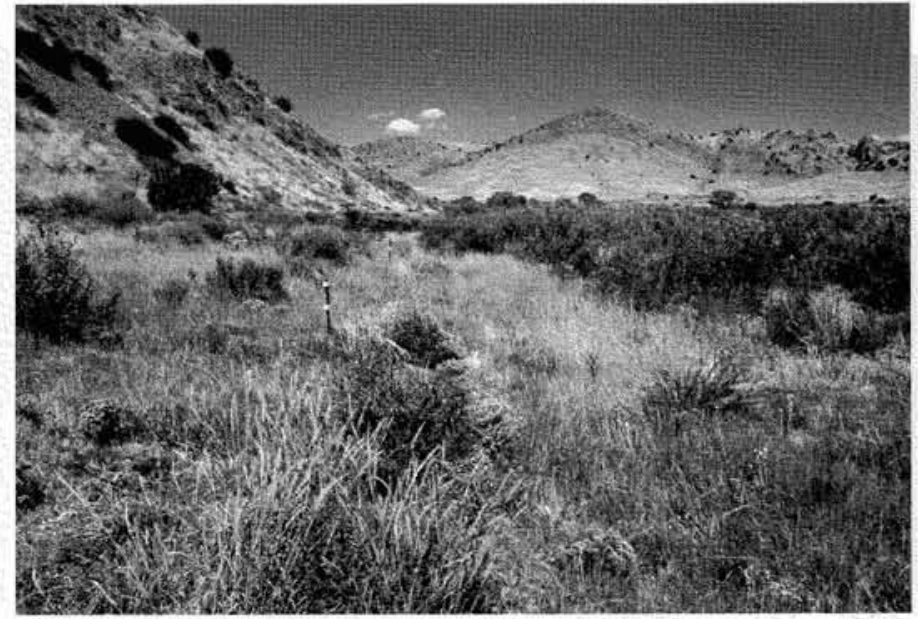

September 2000-"After" electric fence construction and dormant season use-nothing more.

rancher Terry Wheeler to employ his cows (which he calls "four-legged organic soil-builders") to reclaim an eroding mine tailing using grass seed and hay in a method we call a "poop-and-stomp." Near Taos, ranchers Mike Jones and Tony Benson are using the same idea in a sea of sagebrush, along with a technique called "low-stress livestock handling," in an attempt to restore health to badly damaged land.

On the Valle Vidal unit of the Carson National Forest, located east of Costilla, New Mexico, we are working with the Valle Vidal Grazing Association, which employs a herder, various state agencies, the Forest Service, and members of two fishing groups to reduce sediment in Comanche Creek and help restore habitat for the native Cutthroat trout, a species on the verge of being listed under the Endangered Species Act. We hope this EPA-funded project can serve as a model of collaboration and innovation for others.

Our goal in all this work is to demonstrate how new ideas in ranch management can promote ecological recovery and maintenance, creating a "winwin" for everyone. Ranching is not the zero-sum game as many of its critics would have us believe that ecological recovery can advance only as far as cattle can retreat. But neither is the opposite true anymore - that rural economic and cultural viability requires sticking to the "old school" of range management. In our view, evolution appears to be the only option.

However, while change is inevitable, it need not be painful - not if you have friends. 


\section{The New Ranch}

Seven years after our founding, the pursuit of our "golden dream" has grown less elusive. That's because through our involvement with progressively managed ranches, our educational program of workshops, speaking engagements, conferences and a myriad of other outreach activities, we have discovered that other collaborative efforts, other ranches, and other agencies are making progress toward similar goals.

Some of this work is focused on stewardship, such as the award-winning collaboration between the Forest Service and the ranchers of the West Elk Pool which herds 800-head of cattle through a 90,000 -acre federally designated wilderness area in the mountains above Paonia, Colorado. Some of it is focused on the delivery of healthier food, such as the James Ranch, located north of Durango, which produces grassfed beef and organic cheeses. Some of it is concentrated on ecological restoration and the prevention of land fragmentation, such as the Malpai Borderlands Group, located in southeastern Arizona.

Some of this work is being done by ranchers focused on creating conservation values on their land that can help pay the bills, such as developing recreational opportunites. For example, a fox hunting club in Colorado Springs pays the Chico Basin Ranch hard cash for the privilege of blowing bugles and riding across the range in fancy red jackets. On the other end, some landowners are trying to figure out how they can be compensated for producing ecological services, such as cleaner and more abundant water, to cities.

Another example is "grassbanking." This involves utilizing a stretch of open country as a temporary ranch for cattle while the home ground is rested and restored ecologically. This innovative strategy allows ranchers to stay in business while necessary ecological work gets done. The Valle Grande Grassbank on Forest Service land east of Santa Fe has been a model of success, even in dry times.

The list goes on and on. In all cases the sense of urgency is equal to the level of innovation. Ranching is on the ropes. The reasons are multiple, complex, and daunting, including a seductive and rapid rise in the value of rural land for non-agricultural purposes. But it is not just ranching that finds itself in dire straits. Many values prized by urban

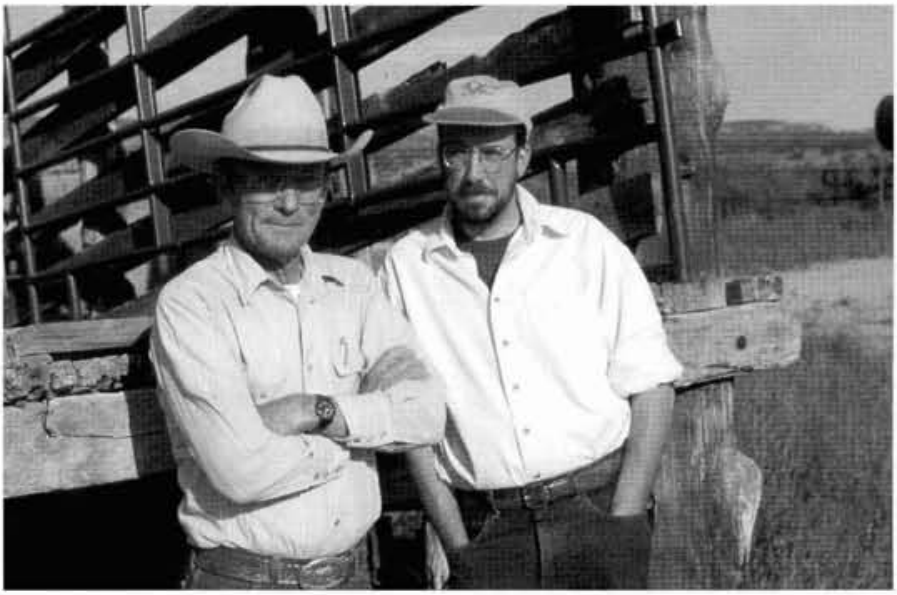

Rancher Jim Williams and conservationist Courtney White, members of Radical Center.

residents across the country are in jeopardy as well, including the viability of wildlife populations, which depend on private land ranches. Additionally, many Americans feel that cultural diversity is as important as biological diversity.

It is to these challenges, as well as opportunities, that many westerners are now turning.

Whether it be grassbanks, dormant season grazing, herding, low-stress livestock handling, poopand-stomps, grassfed food, planned grazing or any number of other innovative models of good stewardship and entrepreneurship, it seems clear that the future of livestock management in the West is pointing in one direction - out of the box. If ranching is to survive, it is these "New Ranchers" that will lead the way. The road will be rocky at first, but with time, and a little luck, it will smooth out, especially if many hands help.

Not every idea will work, and not every collaboration will succeed, but there are enough organizations and individuals now working together on a shared future that it might be time to officially revive author Wallace Stegner's declaration that the West is "the native home of hope."

\footnotetext{
About the Author: Courtney White serves as the Executive Director of the New Mexico-based Quivira Coalition. The coalition's annual conference will be January 15-17, 2004 at the Hilton Hotel, Albuquerque, NM with the theme Ranching in Nature's Image: Fostering Social and Environmental Health in the West. For more information visit www.quiviracoalition.org.
} 